OPEN ACCESS

Edited by:

Estefanía Carrillo-Perdomo, INRA Centre Dijon Bourgogne

Franche-Comté, France

Reviewed by:

Mary Lubungu,

Indaba Agricultural Policy Research Institute, Zambia Frank Mugagga

Makerere University, Uganda

*Correspondence:

Joshua S. Okonya

j.okonya@yahoo.com

orcid.org/0000-0002-9874-5021

Specialty section:

This article was submitted to Nutrition and Sustainable Diets, a section of the journal

Frontiers in Sustainable Food Systems

Received: 09 April 2021

Accepted: 25 June 2021

Published: 23 July 2021

Citation:

Okonya JS, Mudege NN, Nyaga JN and Jogo W (2021) Determinants of

Women's Decision-Making Power in

Pest and Disease Management:

Evidence From Uganda.

Front. Sustain. Food Syst. 5:693127.

doi: 10.3389/fsufs.2021.693127

\section{Determinants of Women's Decision-Making Power in Pest and Disease Management: Evidence From Uganda}

\author{
Joshua S. Okonya ${ }^{1 *}$, Netsayi N. Mudege ${ }^{2,3}$, John N. Nyaga ${ }^{4}$ and Wellington Jogo ${ }^{5}$ \\ ${ }^{1}$ Crop and Systems Sciences Division, International Potato Center, Kampala, Uganda, ${ }^{2}$ Social and Nutritional Sciences \\ Division, International Potato Center, Nairobi, Kenya, ${ }^{3}$ Sustainable Aquaculture Program, WorldFish, Lusaka, Zambia, \\ ${ }^{4}$ Department of Agricultural Economics, University of Nairobi, Nairobi, Kenya, ${ }^{5}$ Social and Nutritional Sciences Division, \\ International Potato Center, Maputo, Mozambique
}

Using quantitative data from a household survey carried out in Rubanda district, Southwestern Uganda among smallholder farmers of potato, this paper examines determinants of intra-household decision-making of women in relation to pest and disease management in a cropping season. Pests and diseases cause significant crop losses and contribute to household food insecurity in most of sub-Saharan Africa. Their management is therefore key in enhancing food security. While there are many pest and disease management practises, little is known about women's autonomy in decision-making on this topic. The survey collected quantitative data from 260 households (130 men and 130 women). To get a more accurate proxy for decision-making power, a weighted index and linear regression models were used to examine the relationship between decision-making power of women in pest and disease management and socio-demographic characteristics. We found that farming experience, use of hired labour and membership to a farmers group, were positively associated with woman's autonomy in decision-making during pest and disease management. Our data also show that higher levels of education, farm income and age consistently improve women authority. The implications of the study are that, women should equally be targeted during pest and disease management interventions such as training.

Keywords: plant health, gender, smallholder farmers, empowerment, intra household bargaining, agricultural productivity

\section{INTRODUCTION}

Power distribution within a household is often linked to women empowerment and gender inequality. Collective decision-making models assume that household decisions are the outcome of a bargaining process among individuals within a household (Chiappori, 1988). Understanding intra-household decision-making for pest and disease management is important because the choices that husbands and wives make within a household regarding crop management affect crop productivity and hence contribute to household food and nutritional security. This interaction between men and women within households is a complex and dynamic process that determine bargaining power of each spouse (Agarwal, 1997). In this paper, we define women autonomy or 
decision-making power as "an opportunity to make choices that affect her life" (Jejeebhoy, 2000). On the other hand, empowerment is defined as "the expansion in people's ability to make strategic life choices in contexts where this ability had been denied to them" (Kabeer, 1999). Women's active participation in decision-making indicates their power within the household. Agricultural decisions are not undertaken by a unitary household (Duflo and Udry, 2004). Duflo and Udry (2004) suggest that, men and women have unequal access to inputs and labour because of skewed decision-making within the household where men have the power to make decisions on household resource allocation. This lack of equal access to resources also curtail women's ability to make decisions.

Research in Uganda has shown that although men may make most decisions, women play an important role in pest and disease management (Erbaugh et al., 2003). It has been noted that not sufficiently engaging women in Integrated Pest Management (IPM) processes can constrain the benefit that IPM practices have to offer (Norton et al., 2005). It has been noted that "the role that gender plays in decision-making and how benefits are distributed within households may affect the success of an IPM program" (Norton et al., 2005). In Uganda some research has illustrated that although men were likely to purchase and apply pesticides than women, women were just as likely as to also have pesticides applied on their fields (Kawarazuka et al., 2020). This brings to the fore the need to understand the process in which decision-making on pest control methods are made in the home.

Gender inequality may be a constraint to adoption of IPM (Norton et al., 2005). A study in the Caribbean noted that women were more dependent on pesticides than men because they were not targeted for training on IPM (Norton et al., 2005). Globally, notable gaps have been reported between men and women in terms of adoption of pest and disease control technologies and this together with other factors, perpetuates gender inequality (FAO, 2011).

There is evidence in other fields such as health that women autonomy within a household increased adoption by women of positive health practices such as birth control (Prata et al., 2017). While, no such studies exist for pest and disease management in Uganda, the effect of autonomy in decision-making on women's ability to adopt technologies may be similar. Women who are more educated and have substantial wealth have been shown to be more assertive and self-confident when making decisions about their personal health (Singh et al., 2002). Women in nuclear families and older women have been reported to participate more in decision-making that young women in extended families (Sathar and Kazi, 1997). Unemployment, living in rural areas, religion (being Muslim) are some of the other factors that have been reported elsewhere to reduce women participation in decision-making (Kritz and MakinwaAdebusoye, 1999; Feyisetan, 2000; Acharya et al., 2010). Agarwal (1997), also found that intrahousehold bargaining power of women in India was strongly influenced by social norms in a given locality.

There is a growing body of literature that link increased household food security and family well-being to higher participation of women in decision-making within a household
(Manfre et al., 2013; Sell and Minot, 2018). Understanding these intra-household differences in the roles of men and women during pest and disease management will not only help agricultural extension workers target the right gender for training in pest and disease management but will also guide future outreach projects on how to design or package gender-responsive IPM strategies.

While in Uganda, there has been studies on IPM and gender, this paper contributes to the gender debate by answering the following questions in relation to management of pests and diseases in potato: (1) Which socio-demographic factors influence women's autonomy during decision-making in pest and disease control? (2) What level of autonomy do women have when making decisions regarding IPM components?

\section{Context}

Uganda is a food basket for the East African region exporting food including potato to neighbouring countries of Rwanda, DR Congo, Kenya, and South Sudan (Ferris et al., 2003). Potato is a major food crop in Uganda mainly grown for both income and food security (Mukiibi, 1972; Musinguzi, 2007). Women are often in-charge of household food production and therefore understanding of the perceived decision-making autonomy of Ugandan women in decisions on pest and disease management for potato is important. For example, it has been suggested that IPM with strong cultural components is the most promising strategy to control most pests and diseases of potato in Uganda (Namanda et al., 2004; Okonya and Kroschel, 2015). Understanding the decision-making process is critical to inform strategies on how to intervene and who to target with interventions aimed at controlling pests and diseases thereby increasing farm productivity. From this perspective, it is important to understand intra-household decision-making and division of labour to design effective IPM programs.

\section{MATERIALS AND METHODS}

\section{Study Area and Design}

This was a cross-sectional study conducted in Muko subcounty in Rubanda district (formerly part of Kabale district, coordinates: $\left.01^{\circ} 11^{\prime} \mathrm{S} 29^{\circ} 51^{\prime} \mathrm{E}\right)$, Uganda in November/December 2016. The study area was selected because potato is a key crop that is widely grown in the area. Rubanda is a highland district at the elevation of 1,219 $\mathrm{m}$ and 2,347 $\mathrm{m}$ above sea level and is the main potato production region suppling Uganda urban markets and neighbouring Rwanda and DR Congo. The topography is mainly green, interlocking and heavily cultivated hills with spectacular valleys. A structured questionnaire was developed and pretested in Wakiso district for cultural suitability and clarity of questions. Seventeen pest and disease control practises were used in the questionnaire to capture (i) who in the family had made the decision regarding a pest and disease control method, (ii) the level of participation in decision-making and work. The level of participation in decision-making and work was self-reported based on the previous cropping season. It's a perception of how often a given spouse within a household participated in doing a given farm activity or in decision-making. 


\section{Ethics (Verbal Informed Consent)}

Prior to conducting face-face individual interviews, the objectives of the study were explained to the participants. Farmers were informed that their participation was voluntary and the information they provided be treated confidentially and anonymised. Participants were informed that they were free to refuse participation, free to refuse to answer any question as well as to stop the interview at any time without fear of negative consequences. No ethical approval of the questionnaire used in this study was needed because it was non-intrusive, did not involve any ethical dilemmas and did not involve any degree of risk of harm to the farmers.

\section{Sampling Procedure and Inclusion Criteria}

Households along accessible roads traversing the subcounty were randomly selected for interviews. Eligible participants for this individual interview included only married men or women living with the spouse and in a monogamous marriage. For each selected household, either the husband or the wife was interviewed. The reason for selecting only spouses in monogamous marriages was based on the authors' experience and field observations in Uganda, that power dynamics within a household can be better measured in monogamous couples, this is because in polygamous marriages, spouses tend to have separate fields/crops. And each person is responsible for making decisions regarding their plot and providing labour for it as well. Two hundred and sixty households (130 men and 130 women) were interviewed by five enumerators (three male and two female) in either the local languages "Rukiga" or in English.

\section{Data Analysis}

\section{Variables Associated With Women's Decision-Making Power}

Factors such as household head, experience in farming, total household size, use of family or hired labour in production of potatoes and belonging to a farmer group were assessed on how they influenced women's decision-making power in the use of IPM. Also factors such as area/size of plot under potato, age of household head and total farm income were regressed against the decision-making index. The variables used to come up with the decision-making index were drawn from conceptual frameworks presented in literature (Haque et al., 2011; Ilesanmi, 2018).

\section{The Linear Regression Models}

Data were analysed using STATA (version 14). Descriptive statistics such as means, percentages and frequencies were used to describe the socio-economic demographics. Linear regression modelling was used to analyse the factors influencing woman's decision-making power in relation to use of IPM in production of potatoes in Uganda (Equation 1).

$$
\begin{aligned}
\mathrm{Y}(\mathrm{DMI})= & \mathrm{B} 0+\mathrm{B} 1^{*} \mathrm{X} 1+\mathrm{B} 2^{*} \mathrm{X} 2+\mathrm{B} 3^{*} \mathrm{X} 3+\mathrm{B} 4^{*} \mathrm{X} 4+\mathrm{B} 5^{*} \mathrm{X} 5 \\
& +\mathrm{B} 6^{*} \mathrm{X} 6+\mathrm{B} 7^{*} \mathrm{X} 7+\mathrm{B} 8^{*} \mathrm{X} 8+\mathrm{B} 9^{*} \mathrm{X} 9
\end{aligned}
$$

Where,

$\mathrm{B} 0=$ the intercept constant
B1-B9 = Coefficient of each independent variable

$\mathrm{X} 1$ = Potato farming experience of husband

$\mathrm{X} 2=$ Total household size

$\mathrm{X} 3$ = Use of family labour

$\mathrm{X} 4=$ Use of hired labour

$\mathrm{X} 5=$ Membership to a farmers group

$\mathrm{X} 6=$ Total land under potato production

X7 = Age of husband (household head)

$\mathrm{X} 8=$ Years of education of wife

$\mathrm{X} 9=$ Total farm income

The dependent variable was decision-making index constructed using exploratory factor analysis (EFA). This was the decision question: "For the previous cropping season, who decided and what was the level of decision-making for the following potato activities in your household." Possible responses for who in the household decided were: $1=\operatorname{man}, 2=$ woman, $3=\operatorname{man}+$ woman, $4=$ woman + children $5=$ man + children, $6=$ All family members, $7=$ others. Possible responses for level of decision-making power were: $1=$ all the time (100\%), $2=$ most of the time (75\%), $3=$ equal time (50\%), $4=$ some of the time (25\%), $5=$ rarely $(<25 \%)$. Respondents who answered "woman" to part 1 of the question and "All the time" to part 2 of the question were considered to have the highest autonomy of the seven groups. For each decision question, we recorded the level of decision-making power of a woman decision maker in a household. Responses were assigned values of four (4), three (3), two (2), and one (1) when the woman was 100 percent, 75 percent, 50 percent, 25 percent involved in making the decision on IPM in potato production, respectively. Decisionmaking index was then constructed from the main IPM decision questions (Table 2).

Prior to data analysis, data were tested for suitability of factor analysis using Bartlett test of sphericity which tests the null hypothesis that variables are not inter-correlated. This was significant at 1 percent thus indicating a strong relationship among the variables. Kaiser-Meyer-Olkin (KMO) which is a Measure of Sampling Adequacy (MSA) was used to test if the variables will factor well considering the correlations. The KMO test result was 0.788 which is above the threshold of 0.5 for the matrix to be considered factorable (Kaiser, 1970; Kaiser and Rice, 1974; Hansson and Lagerkvist, 2012). Considering the two tests, the data was suitable for factor analysis. Cronbach's alpha values were also used to test for reliability of the decision-making index and was found to be 0.7927 . This demonstrated adequate reliability of the factors. A linear combination, determined through a factor analysis, of the individual responses to each decision question. Due to limited literature of the factors that influence women decision-making power in pest management, choice of variables was based on theoretical literature, hypothesis and data availability.

Prior to estimating the linear regression model, several diagnostic tests were carried out. Presence of Multicollinearity was assessed using Variance Inflation Factor (VIF). According to Gujarati (Gujarati, 2009), if the VIF exceeds 10 then there is presence of multicollinearity. In the current study, all the 
variables used in the model had a VIF $<2$ with a mean VIF of 1.46 .

The problem of heteroskedasticity in the model was corrected by estimating robust standard errors as suggested by Wooldridge (Wooldridge, 2003). To test whether the model was correctly specified, Link test was used. If the model is correctly specified one should not find additional independent variables that are statistically significant. STATA uses an additional variable "hat squared" to test this which should not be statistically significant for a properly specified model (Pregibon, 1980). The linear regression model had insignificant "hat squared" variables of 0.169 which indicates that the models did not have any omitted relevant variables thus they were correctly specified. A T-test was also conducted to determine whether there was significant difference between the means of variables among male and female respondents such as education, age, and farming experience.

\section{RESULTS}

\section{Socio-Economic Characteristics of the Sampled Population}

The characteristics of men and women included in the study are shown in Table 1. Apart from average total land size and total farm income, no statistically significant difference was observed between responses by men and women. On average, husbands were older than their wives by 5-6 years. Husbands were on average more educated that their wives by 2-6 school years. Husbands reported larger land pieces owned compared to their wives. The highest proportion of both male and female respondents (about two third) perceived themselves to have medium wealth (like others) in their community. The total household income reported by female respondents was less than a half of what male respondents were reporting.

\section{Decision-Making About Pest and Disease Control}

On average, the highest proportion of women (51\%) reported making decisions related to pest and disease control 50\% of the time, followed by most of the time (35.4\% responses) (Table 2 ). A considerable proportion of women $(35.4 \%)$ made decisions regarding pest and disease control most of the time. Nearly three quarters of the women (73\%) reported making decisions most of the time during mixing of pesticides before field application.

\section{Factors Associated With Women Making Decisions During Pest and Disease Management}

Results of linear regression models used to identify factors associated with woman decision-making power during pest and disease control are shown in Table 3. Factors that had a positive and significant association with woman decision-making power included: Experience of household heads in farming potato, membership to farmers group, years of education of wife and total farm income. Only two variables (use of hired labour in potato production and age of household head) were negatively and significantly associated with women decision-making power in pest and disease management decisions.

\section{Labour Allocation in Relation to Women Decision-Making Power}

To determine the influence of a woman's decision-making power had in relation to labour allocation in different production activities, Pearson correlation coefficient was used. The coefficient measured the strength and direction of association between decision-making power and labour allocation in different production activities by women. In the current study, a positive correlation coefficient indicated an increase in the number of days a woman allocated to an activity in production of potato while a negative correlation coefficient indicated a reduction in the number of days. In the current study, family labour dynamics had a more positive correlation to decisionmaking power of a woman than hired labour at 1 percent, 5 percent, and 10 percent significance levels (Table 4).

\section{DISCUSSION}

We found that farming experience, use of hired labour and membership to a farmers group, were positively associated with woman's autonomy in decision-making during pest and disease management. Our data also show that higher levels of education, farm income and age consistently improve women authority. Similar to what was reported by Sell and Minot (2018) and Kritz and Makinwa-Adebusoye (1999), findings of the current study also found a positive relationship between woman's power in decision-making and her age, as well as education level. Older and highly educated women are taken to be mature persons who can make good and well-informed decisions for the family wellbeing (Anderson et al., 2017). Although not investigated in the current study, the difference in the years of formal education between husband and wife was reported to be more important in increasing a married woman's level of decision-making than the education level of the woman. Implying that development efforts should be directed towards having equal years of formal education for both girls and boys at all levels other than only focusing on increasing school enrolment rates. Peterman et al. (2015) also found that in Uganda, a woman's age increased the level of participation in decision-making.

It is possible that the positive influence of membership to farmers organisation to women's empowerment observed in the current study could be due the skill development trainings received by women from development organizations that specifically target women. Many women in Uganda are now part of village savings and credit associations and members of such farmer cooperatives often receive training in several skills including financial literacy, record keeping, proper agronomic practices, maternal health, confidence building and leadership among others (Mukhooli, 2015). Memberships to farmer cooperatives or groups in Uganda has been reported to not only increase a woman decision-making power within a household but also to increase adoption of better farming practises and economic wellbeing (Lecoutere, 2017). Our finding 
TABLE 1 | Household social demographic characteristics of potato farmers in Rubanda district, Uganda, 2016 survey.

\begin{tabular}{|c|c|c|c|c|}
\hline Farm and household characteristic & Male respondents $(n=130)$ & Female respondents $(n=130)$ & df & $p$-value \\
\hline Average age of household head (husband) & 41 & 42 & 258 & 0.46 \\
\hline Average age of wife & 35 & 37 & 251 & 0.17 \\
\hline Total household size & 6 & 7 & 258 & 0.22 \\
\hline Years of education for household heads & 8 & 8 & 258 & 0.25 \\
\hline Years of education of wife & 5 & 2 & 251 & 0.10 \\
\hline Potato farming experience of husband (years) & 18 & 17 & 257 & 0.20 \\
\hline Average total land size (acres) & 5 & 3 & 258 & 0.04 \\
\hline Average land leased (acres) & 1 & 1 & 238 & 0.40 \\
\hline Average land borrowed (acres) & 0 & 0 & 240 & 0.14 \\
\hline Total land under potato production (acres) & 1 & 1 & 258 & 0.31 \\
\hline Distance to nearest produce mkt (mins) & 52 & 62 & 257 & 0.09 \\
\hline Distance to nearest input store (mins) & 66 & 67 & 258 & 0.47 \\
\hline Distance to nearest all weather road (mins) & 21 & 25 & 258 & 0.17 \\
\hline Distance to nearest sub-county (mins) & 73 & 85 & 123 & 0.15 \\
\hline Distance to nearest certified seed source (mins) & 38 & 50 & 121 & 0.08 \\
\hline Distance to nearest health facility (mins) & 51 & 50 & 258 & 0.41 \\
\hline \multicolumn{5}{|l|}{ Wealth Status by sex of the respondent \% } \\
\hline Worse off than others in my community & 14 & 23 & & \\
\hline Medium wealth or the same as others in my community & 72 & 68 & & \\
\hline Better off than others in my community & 15 & 8 & & \\
\hline \multicolumn{5}{|l|}{ Mean Annual income in US\$ by sex of the respondent } \\
\hline Total farm income & 1,345 & 345 & 258 & 0.01 \\
\hline Total off-farm income & 247 & 312 & 258 & 0.33 \\
\hline Total household income & 1,592 & 657 & 258 & 0.02 \\
\hline
\end{tabular}

TABLE 2 | Level of woman decision-making power during pest and disease control among potato farmers in Rubanda district, Uganda, 2016 (\%).

\begin{tabular}{|c|c|c|c|c|}
\hline \multirow[b]{2}{*}{ IPM component/Decision } & \multicolumn{4}{|c|}{ Level of decision-making power by woman (\%) } \\
\hline & All the time & Most of the time & Equal time & Some of the time \\
\hline Monitored the crops for presence of pests and diseases & 0 & 36 & 50 & 14 \\
\hline Decided the method for weed/pest and disease control & 1 & 31 & 47 & 20 \\
\hline Fetched water for use in pesticide application & 1 & 21 & 66 & 12 \\
\hline Mixed the pesticides & 0 & 73 & 22 & 5 \\
\hline Sprayed/Applied the pesticides & 0 & 35 & 61 & 5 \\
\hline Weeded or sprayed herbicides & 1 & 25 & 55 & 19 \\
\hline Guarding against animal pests (cows, goats, game/vermines) & 0 & 29 & 56 & 15 \\
\hline Rouged/uprooted infected plants) & $<1$ & 39 & 50 & 11 \\
\hline Decided the seed storage/vine conservation method and quantity & 1 & 35 & 44 & 20 \\
\hline Decided which variety to conserve & 0 & 34 & 46 & 19 \\
\hline Decided the insecticides/fungicides to purchase/use & 0 & 31 & 64 & 5 \\
\hline Average & 0.4 & 35.4 & 51.0 & 13.2 \\
\hline
\end{tabular}

is in line with that of Sell and Minot (2018) who also reported that membership to local organisations was highly correlated to high levels of decision-making by women.

The explanation for the positive relationship between woman's decision-making power and farming experience of husbands could be because of continuous learning which builds trust, and this could increase the confidence to delegate some decision roles to the woman. More experienced husbands just as any trainer or teacher, can easily delegate their authority than less experienced farmers who are still learning.

Like it was observed in this study among potato farmers, a large gap between the age of the husband and the wife was reported among coffee farmers in western Uganda to have significant negative influence on the decision-making power of women (Meier zu Selhausen, 2016). In our study, use of hired labour negatively influenced the level of decision-making by 
TABLE 3 | Determinants of Woman IPM decision making power in potato production.

\begin{tabular}{lcccc}
\hline Decision-making Index & Coef. & Std. Err. & [95\% Conf. Interval] \\
\hline Potato farming experience of husband & $0.025^{\star *}$ & 0.012 & 0.001 & 0.048 \\
Total household size & -0.029 & 0.030 & -0.088 & 0.030 \\
Use of family labour & -0.179 & 0.184 & -0.542 & 0.184 \\
Use of hired labour & $-0.304^{\star *}$ & 0.150 & -0.60 & -0.008 \\
Membership to a farmers group & $0.286^{\star}$ & 0.162 & -0.034 & 0.606 \\
Total land under potato production & -0.078 & 0.071 & -0.218 & 0.062 \\
Age of husband (household head) & $-0.020^{\star \star}$ & 0.010 & -0.039 & $<-0.001$ \\
Years of education of wife & $0.005^{\star *}$ & $0.003<0.001$ & 0.010 \\
Total farm income & $<0.001^{\star}$ & 0.000 & 0 & $<0.001$ \\
\hline
\end{tabular}

${ }^{\star \star *},{ }^{\star *}$, and ${ }^{\star}$ denote statistical significance at 1,5 , and $10 \%$ levels, respectively. $n=220$; Prob $>F=0.0069 ; R$-squared $=0.0725$.

TABLE 4 | Labour allocation in relation to woman decision making power by potato farmers in Rubanda district, Uganda, 2016 survey.

\begin{tabular}{|c|c|c|c|c|}
\hline \multirow{2}{*}{$\begin{array}{l}\text { Activity in potato } \\
\text { production }\end{array}$} & \multicolumn{2}{|c|}{ Hired labour } & \multicolumn{2}{|c|}{ Family labour } \\
\hline & Coefficient & Significance & Coefficient & Significance \\
\hline Ploughing & 0.192 & 0.38 & -0.408 & 0.13 \\
\hline Ridging & -0.150 & 0.59 & $0.633^{\star \star \star}$ & $<0.01$ \\
\hline Planting & 0.183 & 0.51 & $0.586^{\star \star \star}$ & $<0.01$ \\
\hline $\begin{array}{l}\text { Fertiliser } \\
\text { application }\end{array}$ & $0.539^{\star \star}$ & 0.04 & $0.411^{\star \star}$ & 0.05 \\
\hline Weeding & -0.007 & 0.98 & $0.407^{\star \star}$ & 0.05 \\
\hline $\begin{array}{l}\text { Pesticide } \\
\text { application }\end{array}$ & $0.438^{*}$ & 0.10 & -0.051 & 0.82 \\
\hline Harvesting & 0.234 & 0.40 & 0.296 & 0.17 \\
\hline Sorting/bagging & -0.214 & 0.44 & 0.162 & 0.46 \\
\hline $\begin{array}{l}\text { Transporting to } \\
\text { store }\end{array}$ & 0.076 & 0.79 & -0.149 & 0.50 \\
\hline
\end{tabular}

0-0.19 = very weak correlation, $0.2-0.39=$ Weak, $0.40-0.59=$ Moderate, $0.6-0.79$ Strong, $0.8-1=$ very strong correlation. ${ }^{* * *},{ }^{* *}$, and ${ }^{*}$ denote statistical significance at 1 , 5 , and $10 \%$ levels, respectively.

women within a household. This finding in a way challenges the notion that the low level of participation by women in decisionmaking is mainly due to the triple work burden (productive, reproductive, community management roles) which consume most of their time (Lyon et al., 2017). A possible explanation could be that hiring labour and paying daily wages is usually the domain of the household head (men) because it involves handling money. So, this could be the reason why married women participated less in this activity. One implication of this finding is that, just reducing the work burden of women alone, will automatically not result into their increased participation in decision-making within a household but instead increasing wife's contributions to household expenditures like was observed by Kritz and Makinwa-Adebusoye (1999).

In the current study, we noticed that women potato farmers in Rubanda district are moderately empowered, in that, a third of the respondents reported making decisions related to pest management most of the time and more than half, made decisions equal times with their husbands. This research finding concurs with what other authors reported. For instance Doss et al. (2014) reported that $52 \%$ of women in Uganda jointly owned land with their husbands while Sell and Minot (2018) found that husbands were only significantly more empowered than their wives in only a quarter of the surveyed population. This could be linked to the number of programs both by the government of Uganda and development partners who continuously promote women emancipation and closing the gender gap.

Our data were in agreement with that of several authors who have reported that off-farm income has a positive effect on the level of a woman's decision-making within a household (Kritz and Makinwa-Adebusoye, 1999; Ngome, 2003; Sell and Minot, 2018).

The perception of individual farmers in a community as to which role is "female" or "male" may also have influenced the level of participation in a given activity. For instance, mixing of pesticides is majorly done by women and often regarded as a "female" activity and hence the high proportions of females (nearly three quarters) making decisions and doing the actual task. Overall, the proportion of women who participated in pest and disease management during potato cultivation in the current study (i.e., 51\%) were comparable to the $50 \%$ women participation in agriculture reported in the state of food and agriculture 2010-2011 report (FAO, 2011).

Other studies have reported factors such as the contribution of the wife to household expenditure, religion and ethnicity to influence decision-making at household levels with men making almost all the decisions in highly religious families (Kritz and Makinwa-Adebusoye, 1999; Quaye et al., 2016; Sell and Minot, 2018). The current study however, didn't examine the influence of wife's contribution to household expenditure, percentage of farm income from potato, woman access to individually managed plot within the household, religion, or tribe on decision-making. Future studies can look at these and more socio-economic and cultural factors.

\section{Study Limitations}

Data was obtained through self-reports and such responses are subject to recall and reporting bias. This study also used proxy responses and this has been observed by some authors to face certain biases especially when it comes to one spouse estimating the levels of participation in farm activities and making decisions of another (Alkire et al., 2013). Using proxies could have caused some biassed responses since some men have a tendency to underestimate the true extent of their wives domestic and agricultural activities (Malena, 1994). We also acknowledge that other socio-economic and cultural factors associated with wife's authority should be investigated in future studies. The hilly landscape of the study area made it very difficult to navigate the potato producing households leaving the survey enumerators with the choice of sampling only those households along accessible roads traversing the subcounty. This may have reduced heterogeneity in responses and hence affecting the quality of collected data. The implications of the results from the current study only apply to monogamously married men and 
women and not those in polygamous marriages or unmarried youth. This is because the dynamics of husband and wife power relations in decision making and labour provision change based on the marital status.

\section{CONCLUSIONS}

Presentation of women decision-making power in pest and disease management in potato in Uganda is reported here for the first time. The role played by women in potato pest and disease management cannot be overlooked and women need to equally be targeted for IPM training by agricultural extension workers and development partners. Half of the time, women participated in decision-making regarding pest and disease control. Future projects on potato IPM should be designed with women in mind since they are equally involved in pest and disease management. In order to increase women's autonomy in decision-making during pest and disease management, stakeholders ought to encourage use of hired labour during potato production, and membership to farmers group. It's also key to educate the girl child, discourage early marriages but also specifically target entrepreneur activities that directly boost women's farm income as all these factors contribute to increased women's authority.

\section{REFERENCES}

Acharya, D. R., Bell, J. S., Simkhada, P., Van Teijlingen, E. R., and Regmi, P. R. (2010). Women's autonomy in household decision-making: a demographic study in Nepal. Reprod. Health 7:15. doi: 10.1186/1742-4755-7-15

Agarwal, B. (1997). Bargaining and gender relations: Within and beyond the household. Fem. Econ. 3, 1-51. doi: 10.1080/135457097338799

Alkire, S., Meinzen-Dick, R., Peterman, A., Quisumbing, A., Seymour, G., and Vaz, A. (2013). The women's empowerment in agriculture index. World Dev. 52, 71-91. doi: 10.35648/20.500.12413/11781/ii033

Anderson, C. L., Reynolds, T. W., and Gugerty, M. K. (2017). Husband and wife perspectives on farm household decision-making authority and evidence on intra-household accord in rural Tanzania. World Dev. 90, 169-183. doi: 10.1016/j.worlddev.2016.09.005

Chiappori, P. A. (1988). Rational household labor supply. Econometrica 56, 63-90. doi: $10.2307 / 1911842$

Doss, C., Meinzen-Dick, R., and Bomuhangi, A. (2014). Who owns the land? perspectives from rural Ugandans and implications for large-scale land acquisitions. Fem. Econ. 20, 76-100. doi: 10.1080/13545701.2013.855320

Duflo, E., and Udry, C. (2004). Intrahousehold Resource Allocation in Cote D'ivoire: Social Norms, Separate Accounts, and Consumption Choices. Cambridge, MA: National Bureau of Economic Research.

Erbaugh, M. J., Donnermeyer, J., Amujal, M., and Kyamanywa, S. (2003). The role of women in pest management decision making in Eastern Uganda. J. Int. Agric. Ext. Educ. 10, 71-81. doi: 10.5191/jiaee.2003.10309

FAO (2011). "Women in agriculture-closing the gender gap for development," in State of Food and Agriculture 2010-11, ed R. Terri R (Rome: Food Agriculture Organization of the United Nations), 147.

Ferris, R., Lemaga, B., Okobio, G., Crissman, C., and Ewell, P. (2003). Performance and Growth Prospects of Irish Potatoes as a Component for the Development of Strategic Exports in Uganda: ASARECA Monograph, No. 2. Entebbe: ASARECA.

Feyisetan, B. J. (2000). Spousal communication and contraceptive use among the Yoruba of Nigeria. Popul. Res. Policy Rev. 19, 29-45. doi: 10.1023/A:1006388011947

Gujarati, D. N. (2009). Basic Econometrics, 4th Edn. New York, NY: McGrawHill Education.

\section{DATA AVAILABILITY STATEMENT}

The raw data supporting the conclusions of this article will be made available by the authors, without undue reservation.

\section{ETHICS STATEMENT}

Ethical review and approval was not required for the study on human participants in accordance with the local legislation and institutional requirements. The participants provided their informed consent to participate in this study.

\section{AUTHOR CONTRIBUTIONS}

All authors listed have made a substantial, direct and intellectual contribution to the work, and approved it for publication.

\section{FUNDING}

This research was undertaken as part of and funded by the CGIAR Research Program on Roots, Tubers, and Bananas (RTB) and supported by CGIAR Trust Fund contributors (https://www. cgiar.org/funders/).

Hansson, H., and Lagerkvist, C. J. (2012). Measuring farmers' preferences for risk: a domain-specific risk preference scale. J. Risk Res. 15, 737-753. doi: 10.1080/13669877.2012.657217

Haque, M., Islam, T. M., Tareque, M. I., and Mostofa, M. (2011). Women empowerment or autonomy: a comparative view in Bangladesh context. Bangladesh E-J. Sociol. 8, 17-30. Available online at: http://www. bangladeshsociology.org/BEJS\%208.2\%20Women\%20Empowerment\%20or \%20Autonomy.pdf

Ilesanmi, O. O. (2018). Women's visibility in decision making processes in Africa-progress, challenges, and way forward. Front. Sociol. 3:38. doi: $10.3389 /$ fsoc. 2018.00038

Jejeebhoy, S. J. (2000). "Women's autonomy in rural India: Its dimensions, determinants, and the influence of context," in Women's Empowerment and Demographic Processes: Moving Beyond Cairo, eds H. Presser and G. Sen (New York, NY: Oxford University Press), 204-238.

Kabeer, N. (1999). Resources, agency, achievements: reflections on the measurement of women's empowerment. Dev. Change 30, 435-464. doi: $10.1111 / 1467-7660.00125$

Kaiser, H. F. (1970). A second generation little jiffy. Psychometrika 35, 401-415. doi: $10.1007 / \mathrm{BF} 02291817$

Kaiser, H. F., and Rice, J. (1974). Little jiffy, mark IV. Educ. Psychol. Meas. 34, 111-117. doi: 10.1177/001316447403400115

Kawarazuka, N., Assefa, E., Mayanja, S., Okonya, J. S., Rietveld, A., Slavchevska, $\mathrm{V}$., et al. (2020). A gender perspective on pest and disease management from the cases of roots, tubers and bananas in Asia and sub-Saharan Africa. Front. Agron. 2:7. doi: 10.3389/fagro.2020.00007

Kritz, M. M., and Makinwa-Adebusoye, P. (1999). Determinants of women's decision-making authority in Nigeria: the ethnic dimension. Sociol. Forum 14, 399-424. doi: 10.1023/A:1021495418633

Lecoutere, E. (2017). The impact of agricultural co-operatives on women's empowerment: evidence from Uganda. J. Co-op. Organ. Manag. 5, 14-27. doi: $10.1016 /$ j.jcom.2017.03.001

Lyon, S., Mutersbaugh, T., and Worthen, H. (2017). The triple burden: the impact of time poverty on women's participation in coffee producer organizational governance in Mexico. Agric. Hum. Values 34, 317-331. doi: $10.1007 /$ s10460-016-9716-1 
Malena, C. (1994). Gender Issues in Integrated Pest Management in African Agriculture. Chantham: Natural Resources Institute.

Manfre, C., Rubin, D., Allen, A., Summerfield, G., Colverson, K., and Akeredolu, M. (2013). Reducing the gender gap in agricultural extension and advisory services: how to find the best fit for men and women farmers. Meas. Brief 2 . Available online at: https://meas.illinois.edu/wp-content/uploads/2015/04/ Manfre-et-al-2013-Gender-and-Extension-MEAS-Discussion-Paper.pdf

Meier zu Selhausen, F. (2016). What determines women's participation in collective action? evidence from a western Ugandan coffee cooperative. Fem. Econ. 22, 130-157. doi: 10.1080/13545701.2015. 1088960

Mukhooli, C. (2015). Impact of Microedit Programs on Women's Empowerment in East Africa (Uganda, Kenya, and Tanzania). Murdoch, WA: Murdoch University.

Mukiibi, J. (1972). "The potato as a subsistence and cash crop in Uganda," in International Symposium on Key Problems and Potentialsfor Greater Use of the Potato in Dev World July; Lima, peru, ed E. R. French (Lima: International Potato Center), 32-39.

Musinguzi, G. (2007). Kabale Farmers Reap Millions From Irish Potato Sales. Kampala: Uganda Radio Network.

Namanda, S., Olanya, O., Adipala, E., Hakiza, J., El-Bedewy, R., Baghsari, A., et al. (2004). Fungicide application and host-resistance for potato late blight management: benefits assessment from on-farm studies in SW Uganda. Crop Protect. 23, 1075-1083. doi: 10.1016/j.cropro.200 4.03.011

Ngome, A. N. (2003). Gender Division of Labor and Women's Decision-Making Power in Rural Households: The Case of Mbalangi, Ediki and Mabonji Villages of Meme Division. Buea: University of Buea.

Norton, G. W., De Datta, S., Irwin, M. E., Rajotte, E. G., and Heinrichs, E. (2005). The Need for Cost-Effective Design and Diffusion of IPM. Globalizing Integrated Pest Management: A Participatory Research Process. Oxford: Blackwell Publishing, $1-11$.

Okonya, J. S., and Kroschel, J. (2015). A cross-sectional study of pesticide use and knowledge of smallholder potato farmers in Uganda. BioMed. Res. Int. 2015:759049. doi: 10.1155/2015/759049

Peterman, A., Schwab, B., Roy, S., Hidrobo, M., and Gilligan, D. O. (2015). Measuring Women's Decisionmaking: Indicator Choice and Survey Design Experiments From Cash and Food Transfer Evaluations in Ecuador, Uganda, and Yemen. Washington, DC: International Food Policy Research Institute.
Prata, N., Fraser, A., Huchko, M. J., Gipson, J. D., Withers, M., Lewis, S., et al. (2017). Women's empowerment and family planning: a review of the literature. J. Biosoc. Sci. 49, 713-743. doi: 10.1017/S0021932016000663

Pregibon, D. (1980). Goodness of link tests for generalized linear models. J. R. Stat. Soc. Ser. C (Appl. Stat.) 29, 15-24. doi: 10.2307/2346405

Quaye, W., Dowuona, S., Okai, M., and Dziedzoave, N. (2016). Gender dimensions of decision-making on production assets and challenges facing women. Dev. Pract. 26, 77-90. doi: 10.1080/09614524.2016.1112364

Sathar, Z. A., and Kazi, S. (1997). Women's Autonomy, Livelihood, and Fertility: A Study of Rural Punjab. Islamabad: Pakistan Institute of Development Economics.

Sell, M., and Minot, N. (2018). What factors explain women's empowerment? Decision-making among small-scale farmers in Uganda. Womens Stud. Int. Forum 71, 46-55. doi: 10.1016/j.wsif.2018.09.005

Singh, K., Singh, K., Singh, B., and Pathak, A. (2002). Impact of education and autonomy on fertility of women in eastern Uttar Pradesh. Demogr. India 31, 223-233. Available online at: https://www.researchgate.net/publication/ 273125077_Impact_of_Education_and_Autonomy_on_Fertility_of_Women_ in_Eastern_Uttar_Pradesh

Wooldridge, J. M. (2003). Introductory Econometrics: A Modern Approach. New York, NY: South-Western College Publishing.

Conflict of Interest: The authors declare that the research was conducted in the absence of any commercial or financial relationships that could be construed as a potential conflict of interest.

Publisher's Note: All claims expressed in this article are solely those of the authors and do not necessarily represent those of their affiliated organizations, or those of the publisher, the editors and the reviewers. Any product that may be evaluated in this article, or claim that may be made by its manufacturer, is not guaranteed or endorsed by the publisher.

Copyright (C) 2021 Okonya, Mudege, Nyaga and Jogo. This is an open-access article distributed under the terms of the Creative Commons Attribution License (CC BY). The use, distribution or reproduction in other forums is permitted, provided the original author(s) and the copyright owner(s) are credited and that the original publication in this journal is cited, in accordance with accepted academic practice. No use, distribution or reproduction is permitted which does not comply with these terms. 